\title{
PENGARUH PEMBIAYAAN MURABAHAH, MUDHARABAH, DAN BIAYA OPERASIONAL TERHADAP RETURN ON ASSET BANK UMUM SYARIAH DAN UNIT USAHA SYARIAHDI INDONESIA
}

\author{
Ika Meutia, Syawal Harianto, Khairil Fata \\ Jurusan Tata Niaga, Prodi Akuntansi Lembaga Keuangan Syariah \\ Politeknik Negeri Lhokseumawe \\ E-mail :ika.meutia1011@gmail.com \\ syawalharianto@pnl.ac.id \\ khairilfata@pnl.ac.id
}

\begin{abstract}
This study aims to explain the Influence of Murabahah Financing, Mudharabah, and Operational Costs on Return On Assets of Sharia Commercial Bank and Sharia Business Unit in Indonesia period 2014-2017. The sample technique used is the sample census, where the entire population is taken into a sample. The sample is 13 sharia commercial banks and 21 units of sharia business. This research data is sourced from sharia banking statistics obtained from official website of Otoritas Jasa Keuangan (OJK). Data analysis technique using multiple linear regression analysis. Where previously classic assumption test has been performed which includes normality test, multicollinearity test, and heteroscedasticity test. The result of $F$ test shows that simultaneously Murabahah, Mudharabah, and Operational Cost variables have significant effect on return on asset. The result of $t$ test shows that partially murabahah financing variables have positive and significant effect to return on asset, mudharabah have positive and not significant return on asset, and operational cost have negative and not significant effect to return on asset.
\end{abstract}

Keyword :Murabaha, Mudharaba, operational cost, return on asset

\section{PENDAHULUAN}

Perbankan syariah semakin menunjukkan eksistensinya di industri perbankan Indonesia.Hal tersebut terjadi setelah adanya pengesahan UU No. 21/2008 mengenai perbankan syariah.Berdasarkan data dari Otoritas Jasa Keuangan, sekarang telah berdiri 13 Bank Umum Syariah, 21 Unit Usaha Syariah, dan 167 Bank Pembiayaan Rakyat Syariah. (Statistik Perbankan Syariah, 2017).

Sebagai salah satu lembaga keuangan, bank perlu menjaga kinerjanya agar dapat beroperasi secara optimal. Terlebih lagi bank syariah harus bersaing dengan bank konvensional yang dominan dan telah berkembang pesat di Indonesia. Persaingan yang semakin tajam ini harus dibarengi dengan manajemen yang baik untuk bisa bertahan di industri perbankan.Salah satu faktor yang harus diperhatikan oleh bank untuk bisa terus bertahan ditengah kerasnya persaingan adalah kinerja keuangan bank.

Secara umum, besar kecilnya keuntungan yang diperoleh oleh bank salah satunya ditentukan dengan return dari jumlah pembiayaan yang disalurkan. Selain itu, besar kecilnya tingkat keuntungan juga dipengaruhi oleh biaya operasional yang dikeluarkan.Ukuran keuntungan yang diperoleh disebut dengan profitabilitas.Rasio profitabilitas yang digunakan dalam penelitian ini adalah 
Return On Asset. Return On Assetadalah rasio yang menggambarkan seberapa jauh kemampuan bank menghasilkan laba dari hasil pengelolaan aset yang dimilikinya. Return On Asset dapat dilihat dengan cara membandingkan laba bersih dengan total aset.

Berikut ini adalah data rata-rata total pembiayaan murabahah, mudharabah, biaya operasional dan return on asset BUS dan UUS di Indonesia

\section{Tabel 1}

Rata-rata pembiayaan murabahah, mudharabah, biaya operasional dan roa

\begin{tabular}{|c|c|c|c|c|}
\hline Tahun & Murabahah & Mudharabah & Biaya Operasional & ROA \\
\hline 2014 & 113,507 & 14,027 & 12,131 & $0.85 \%$ \\
\hline 2015 & 118,418 & 14,873 & 13,554 & $1.36 \%$ \\
\hline 2016 & 128,624 & 15,103 & 14,409 & $1.39 \%$ \\
\hline 2017 & 144,021 & 15,562 & 13,302 & $1.75 \%$ \\
\hline
\end{tabular}

Tabel 1 menunjukkan bahwa selama periode 2014-2017 pembiayaan murabahah lebih mendominasi pembiayaan pada bank umum syariah dan unit usaha syariah di Indonesia karena lebih besar dari pembiayaan mudharabah. Pembiayaan murabahah terus mengalami peningkatan setiap tahun.Peningkatan pembiayaan murabahah juga dibarengi dengan meningkatnya ROA setiap tahun.Pembiayaan mudharabah juga mengalami peningkatan setiap tahun namun tidak sebesar peningkatan yang terjadi pada pembiayaan murabahah.Biaya operasional yang dikeluarkan bank umum syariah dan unit usaha syariah mengalami peningkatan setiap tahun namun pada tahun 2017 mengalami penurunan.

Berdasarkan uraian di atas peneliti tertarik untuk meneliti variabel mana yang paling dominan mempengaruhi Return On Asset (ROA) bank umum syariah dan unit usaha syariah di Indonesia. Adapun yang menjadi rumusan masalah dalam penelitian ini adalah sebagai berikut: apakah Pembiayaan Murabahah, Mudharabah, dan Biaya Operasional secara simultan dan parsial berpengaruh signifikan terhadap Return On Asset Bank Umum Syariah dan Unit Usaha Syariah di Indonesia periode 2014-2017.

\section{KAJIAN PUSTAKA}

\section{Return On Asset}

Return On Assetadalah rasio yang melihat sejauh mana aset yang telah ditanamkan mampu memberikan pengembalian keuntungan sesuai dengan yang diharapakan. Menurut (Irham,2012:82) Sedangkan menurut Kasmir (2010:201) "Return On Asset adalah Hasil pengembalian investasi atau lebih dikenal dengan nama Return On Investment (ROI) atau Return On Total Asset merupakan rasio yang menunjukkan hasil (return) atas jumlah aktiva yang digunakan dalam perusahaan. ROI juga merupakan suatu ukuran tentang efektivitas manajemen dalam mengelola investasinya.

Dalam kerangka penilaian kesehatan bank, BI akan mendapatkan skor maksimum apabila bank memiliki ROA sebesar 1,05\% (Hasibuan, 2006:101). Menurut surat ketetapan Bank Indonesia no. 23/67/KEP/DIR, nilai batas minimal ROA adalah $1 \%$. Jika nilai ROA berada dibawah $1 \%$ maka perusahaan tersebut berada pada zona tidak aman.

\section{Pembiayaan Murabahah}

Murabahah adalah akad jual beli atas abarang tertentu, dimana penjual menyebutkan harga pembelian barang kepada pembeli kemudian menjual kepada pihak pembeli dengan mensyaratkan keuntungan yang diharapkan sesuai jumlah tertentu. (Ismail, 2015:138) 
Menurut Nurhayati dan Wasilah (2009:160), murabahah adalah transaksi penjualan barang dengan menyatakan harga perolehan dan keuntungan (margin) yang disepakati oleh penjual dan pembeli.Pembayaran atas akad jual beli dapat dilakukan secara tunai atau tangguh.

\section{Hubungan Pembiayaan Murabahah Terhadap Return On Asset}

Pembiayaan Murabahah merupakan salah satu produk paling popular dalam industri perbankan syariah. Pembiayaan murabahah juga merupakan salah satu komponen penyusun aset terbesar pada perbankan syariah dan akan menghasilkan pendapatan berupa margin. Atas perolehan margin tersebut maka akan mempengaruhi besarnya laba yang diperoleh, sehingga akan meningkatkan profitabilitas yang tercermin dari Return On Asset.

Wicaksana (2011) mengemukakan bahwa semakin tinggi pembiayaan murabahah maka akan semakin meningkatkan profitabilitas bank umum syariah yang diproksikan dengan Return On Asset. Dengan demikian dapat dikatakan bahwa pembiayaan murabahah adalah salah satu komponen penting bagi tingkat profitabilitas bank syariah.

\section{Pembiayaan Mudharabah}

Mudharabah akad kerja sama usaha antara dua pihak di mana pihak pertama (shahibul mal) menyediakan seluruh (100\%) modal, sedangkan pihak lainnya menjadi pengelola. Keuntungan usaha secara mudharabah dibagi menurut kesepakatan yang dituangkan dalam kontrak, sedangkan apabila rugi ditanggung oleh pemilik modal selama kerugian itu bukan akibat atau kelalaian si pengelola. (Antonio, 2001:95)

Pemberian pembiayaan mudharabah yang diberikan bank syariah atas dasar kepercayaan.Karena dalam skema mudharabah bank syariah tidak ikut campur dalam proyek yang dijalankan nasabah, tetapi bank syariah memberikan $100 \%$ modal untuk nasabah.

\section{Hubungan Pembiayaan Mudharabah Terhadap Return On Asset}

Pembiayaan mudharabah merupakan salah satu produk bank syariah dari jenis pembiayaan bagi hasil.Pembiayaan merupakan salah satu komponen penyusun aset yang ikut menentukan besar kecilnya pendapatan bank syariah. Dari hasil pengelolaan pembiayaan tersebut bank syariah akan memperoleh pendapatan bagi hasil sesuai nisbah yang disepakati dengan mitra kerja/nasabah (Muhammad, 2005). Atas perolehan pendapatan bagi hasil tersebut akan mempengaruhi peningkatan profitabilitas yang tercermin dari Return On Asset.

\section{Biaya Operasional}

Menurut Jusuf (2007:33) "Biaya Operasional atau biaya usaha (operating expenses) adalah biaya-biaya yang tidak berhubungan langsung dengan produk perusahaan tetapi berkaitan dengan aktivitas operasinal perusahaan sehari-hari. Biaya usaha sering disebut juga dengan istilah SGA (Selling, General, dan Administrative Expenses)".

Total biaya operasional meliputi: beban imbalan kepada BI, bonus titipan wadiah, Kerugian atas penjualan surat berharga, kerugian dari penyertaan dan beban komisi/provisi, kerugian penurunan nilai aset keuangan dan lainnya, penyusutan/ amortisasi, beban pemeliharaan aset tetap/inventaris, beban risiko operasional, kerugian restrukturisasi pembiayaan, beban tenaga kerja, biaya promosi, premi asuransi, sewa, pajak-pajak (tidak tergolong pajak penghasilan), pemeliharaan,perbaikan aset tetap dan inventaris, barang dan jasa, kerugian dari penjualan aset tetap dan inventaris, serta kerugian dari penjualan transaksi valuta asing (OJK, 2016b).

\section{Hubungan Biaya Operasional Terhadap Return On Asset}

Dalam suatu perusahaan, apabila biaya operasional yang dikeluarkan lebih 
besar dari pendapatan maka perusahaan akan mengalami kerugian, sebaliknya apabila biaya operasional yang dikeluarkan lebih kecil dari pendapatan maka perusahaan akan memperoleh laba/keuntungan. Agar perusahaan bisa memaksimalkan laba maka perusahaan harus mampu menekan biaya operasional yang dikeluarkan.Dengan demikian dapat dikatakan bahwa biaya operasional sangat erat hubungannya dengan tingkat profitabilitas perusahaan.
Menurut Hidayat (2007:27), "Menganggap bahwa pemanfaatan biaya yang rendah dapat dihubungkan secara langsung dengan tingkat profitabilitas yang tinggi”. Dalam pendapat lain menurut Jusuf (2007:35) menjelaskan bahwa, "Bila perusahaan dapat menekan biaya operasional, maka perusahaan akan dapat meningkatkan laba bersih. Demikian juga sebaliknya, bila terjadi pemborosan biaya akan mengakibatkan menurunnya laba bersih".

\section{KERANGKA PEMIKIRAN DAN PERUMUSAN HIPOTESIS}

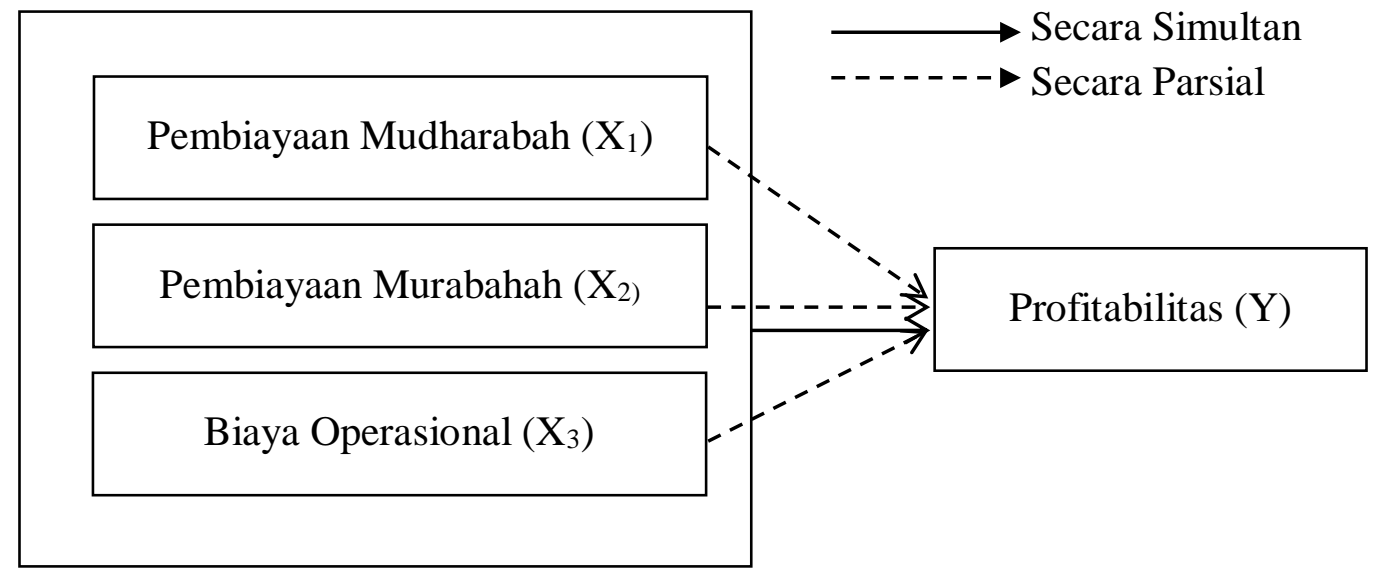

Berdasarkan kerangka pemikiran di atas, maka hipotesis yang diajukan dalam penelitian ini adalah:

1) Pembiayaan Murabahah, Mudharabah, dan Biaya Operasional secara simultan berpengaruh signifikan terhadap Return On Asset Bank Umum Syariah dan Unit Usaha Syariah di Indonesia periode 20142017.

2) Pembiayaan Murabahah secara parsial berpengaruh signifikan terhadap Return On Asset Bank Umum Syariah dan Unit Usaha Syariah di Indonesia periode 2014-2017.

3) Pembiayaan Mudharabah secara parsial berpengaruh signifikan terhadap Return On Asset Bank Umum Syariah dan Unit Usaha Syariah di Indonesia periode 20142017.
4) Biaya Operasional secara parsial berpengaruh signifikan terhadap Return On Asset Bank Umum Syariah dan Unit Usaha Syariah di Indonesia periode 2014-2017.

\section{METODE PENELITIAN \\ Populasi dan Sampel}

Menurut Sugiono (2012:80) "Populasi adalah wilayah generalisasi yang terdiri atas obyek atau subyek yang mempunyai kualitas dan karakteristik tertentu yang ditetapkan oleh peneliti untuk dipelajari dan kemudian ditarik kesimpulan”. Populasi dalam penelitian ini adalah Bank Umum Syariah dan Unit Usaha Syariah yang terdaftar di Bank Indonesia.Pengambilan sampel dalam penelitian ini menggunakan metode sensus, dimana keseluruhan populasi menjadi sampel.Adapun yang menjadi 
sampel dalam penelitian ini adalah 13 Bank Umum Syariah dan 21 Unit Usaha Syariah di Indonesia.

\section{Jenis dan Sumber Data}

Penelitian ini menggunakan data kuantitatif serta menggunakan data sekunder.Data penelitian ini bersumber dari statistik perbankan syariah yang diperoleh dari website resmi Otoritas Jasa Keuangan (OJK).

\section{MetodeAnalisis Data}

Penelitian ini menggunakan metode regresi linear berganda untuk analisa pengaruh variabel bebas terhadap variabel terikat.Model ini dipilih karena penelitian ini dirancang untuk meramalkan variabel terikat berdasarkan variabel bebas. Model yang dimaksud adalah sebagai berikut:

$Y=\alpha+\beta_{1} \operatorname{Ln} X_{1+} \beta_{2} \operatorname{Ln} X_{2}+\beta_{3} \operatorname{Ln} X_{3+} e$

Dimana:

$\mathrm{Y}=$ Return On Asset

$\alpha=$ Konstanta

$\beta=$ Slope

$\mathrm{X}_{1}=$ Pembiayaan Mudharabah

$\mathrm{X}_{2}=$ Pembiayaan Murabahah

$\mathrm{X}_{3}=$ Biaya Operasional

Ln = Logaritma Natural

$\mathrm{e}=$ Error

\section{Uji Asumsi Klasik}

\section{Uji Normalitas}

Uji normalitas berguna untuk menentukan data yang telah dikumpulkan berdistribusi normal atau diambil dari populasi normal.Uji normalitas digunakan untuk menguji apakah dalam sebuah model regresi, variabel independen dan dependen atau keduanya mempunyai distribusi normal atau tidak.Model yang baik adalah data normal atau mendekati normal.

Untuk menguji apakah data berdistribusi normal atau tidak dilakukan uji statistik Kolmogorov-Smirnov Test. Residual berdistribusi normal jika memiliki nilai signifikansi $>0,05$. (Ghozali, 2011:160)

\section{Uji Multikolinearitas}

Menurut Ghozali (2013:105) uji multikolinearitas bertujuan untuk menguji apakah model regresi ditemukan adanya korelasi antar variabel bebas (independen).Metode yang dapat digunakan untuk menguji terjadinya multikolinieritas dapat dilihat dari matrik korelasi variabel-variabel bebas. Pada matrik korelasi, jika antar variabel bebas terdapat korelasi yang cukup tinggi (umumnya di atas 0,90), maka hal ini merupakan indikasi adanya multikolinieritas. Selain itu dapat juga dilihat nilai tolerance dan variance inflation factor (VIF). Batas dari nilai tolerance adalah $\leq 0,10$ atau sama dengan nilai VIF adalah $\geq 10$.

\section{Uji Heteroskedastisitas}

Menurut Ghozali (2013: 139), uji heteroskedastisitas bertujuan untuk menguji apakah dalam model regresi terjadi ketidaksamaan variancedari residual satu pengamat ke pengamat yang lain.

Uji statistik yang lebih dapat menjamin keakuratan hasil, salah satunya dengan uji glejser.Uji Glejser mengusulkan untuk meregres nilai absolut residual terhadap variabel independen.Hasil probabilitas dikatakan signifikan jika nilai signifikansinya diatas tingkat kepercayaan 5\%. (Ghozali, 2013:142)

\section{Pengujian Hipotesis}

\section{Uji Koefisien Determinasi}

Uji $\mathrm{R}^{2}$ digunakan untuk mengetahui proporsi dari keberagaman variabel terikat yang diterangkan oleh model regresi atau untuk mengukur kontribusi dari variabel bebas terhadap keragaman variabel terikat.Nilai koefisien determinasi adalah antara nol dan satu. Nilai $\mathrm{R}^{2}$ yang kecil berarti kemampuan variabel-variabel independen dalam menjelaskan variasi variabel dependen amat terbatas

\section{Uji Signifikansi Simultan}


Pengujian ini bertujuan untuk mengetahui apakah variabel bebas yang dimasukkan dalam model mempunyai pengaruh secara bersama-sama terhadap variabel terikat.

pengujian ini menggunakan uji $\mathrm{F}$ yaitu dengan membandingkan $F_{\text {hitung }}$ dengan $F_{\text {tabel. }}$ Uji ini dilakukan dengan syarat:

a. Bila $\mathrm{F}_{\text {hitung }}<\mathrm{F}_{\text {tabel }}$ maka $\mathrm{H}_{0}$ diterima dan ditolak $\mathrm{H}_{\mathrm{a}}$, artinya bahwa secara bersama-sama variabel independen tidak berpengaruh terhadap variabel dependen

b. Bila $\mathrm{F}_{\text {hitung }}>\mathrm{F}_{\text {tabel, }}$ maka $\mathrm{H}_{0}$ ditolak dan menerima $\mathrm{H}_{a}$ artinya bahwa secara bersama-sama variabel independen berpengaruh terhadap variabel dependen.

Pengujian ini dilakukan pada tingkat signifikasi $(\alpha) 5 \%$. Analisis ini didasarkan pada perbandingan antara nilai signifikasi $F$ dengan nilai signifikasi 0,05 dengan syarat sebagai berikut:

a. Jika signifikasi $\mathrm{F}<0,05$ maka $\mathrm{H}_{0}$ ditolak yang berarti variabel-variabel independen secara simultan berpengaruh terhadap variabel dependen.

b. Jika signifikasi $\mathrm{F}>0,05$ maka $\mathrm{H}_{0}$ diterima yang berarti variabel independen secara simultan tidak berpengaruh terhadap variabel dependen.

\section{Uji Signifikansi Parsial}

\section{HASIL DAN PENELITIAN}

Uji Asumsi Klasik

1. Uji Normalitas

Berikut adalah hasil uji Kolmogorov-

Smirnov:
Pada dasarnya, uji t dilakukan untuk mengetahui apakah semua variabel bebas secara parsial berpengaruh terhadap variabel terikat. Uji dilakukan dengan syarat:

a. Bila $t_{\text {hitung }}>t_{\text {tabel }}$, maka $\mathrm{H}_{0}$ diterima dan ditolak $\mathrm{H}_{\mathrm{a}}$, artinya bahwa secara bersama-sama variabel independen tidak berpengaruh terhadap variabel dependen.

b. Bila $t_{\text {hitung }}>t_{\text {tabel}}$, maka $\mathrm{H}_{0}$ ditolak dan menerima $\mathrm{H}_{\mathrm{a}}$ artinya bahwa secara bersama-sama variabel independen berpengaruh terhadap variabel dependen.

Untuk mengetahui kebenaran hipotesis digunakan kriteria $t$ hitung.Pengujian ini juga dapat menggunakan pengamatan nilai signifikasi t pada tingkat $\alpha$ yang digunakan (penelitian ini menggunanakan tingkat $\alpha$ sebesar 5\%). Analisis ini didasarkan pada perbandingan antara nilai signifikasi $\mathrm{t}$ dengan nilai signifikasi 0,05 dengan syarat-syarat sebagai berikut:

a. Jika signifikasi $\mathrm{t}<0,05$ maka $\mathrm{H}_{0}$ ditolak yang berarti variabel independen secara simultan berpengaruh terhadap variabel dependen.

b. Jika signifikasi $\mathrm{t}>0,05$ maka $\mathrm{H}_{0}$ diterima yang berarti variabel independen secara simultan tidak berpengaruh terhadap variabel dependen

Tabel 2

Uji Kolmogorov-Smirnov

One-Sample Kolmogorov-Smirnov Test

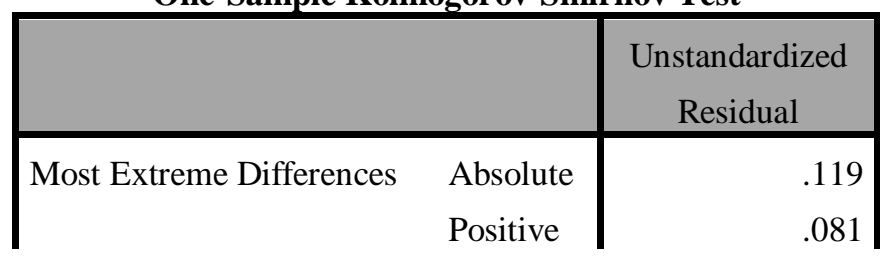




\begin{tabular}{|c|c|c|}
\hline & Negative & -.119 \\
\hline Test Statistic & & .119 \\
\hline Asymp. Sig. (2-tailed) & & $.087^{\mathrm{c}}$ \\
\hline
\end{tabular}
a. Test distribution is Normal.
b. Calculated from data.
c. Lilliefors Significance Correction.

Berdasarkan tabel 2 dapat dilihat bahwa nilai probabilitas signifikan yang diperoleh dari Uji Kolmogorov-Smirnov adalah sebesar 0.087 yang menunjukkan bahwa nilai tersebut lebih besar dari tingkat kekeliruan 5\% (0.05), maka dapat disimpulkan bahwa model regresi terdistribusi normal dan layak dipakai karena memenuhi asumsi normalitas.

\section{Uji Multikolinearitas}

Untuk mengetahui apakah model regresi penelitian ini memenuhi asumsi multikolinearitas, maka dilakukan uji dengan melihat Variance Inflation Factor (VIF) dan nilai Tolerance.Berikut adalah hasil uji multikolinearitas:

Tabel 3

Uji Multikolinearitas

\begin{tabular}{|c|c|c|c|}
\hline \multicolumn{4}{|c|}{ Coefficients $^{\mathrm{a}}$} \\
\hline \multirow{2}{*}{\multicolumn{2}{|c|}{ Model }} & \multicolumn{2}{|c|}{ Collinearity Statistics } \\
\hline & & Tolerance & VIF \\
\hline \multirow[t]{3}{*}{1} & Murabahah & .544 & 1.838 \\
\hline & Mudharabah & .424 & 2.360 \\
\hline & B_Operasional & .591 & 1.692 \\
\hline
\end{tabular}

a. Dependent Variable: roa

Hasil pengujian di atas menunjukkan bahwa tidak terjadinya gejala multikolinearitas karena tidak ada satupun variabel yang memiliki nilai tolerance kurang dari 0,1 dan tidak ada satupun variabel yang memiliki nilai VIF lebih dari 10.

\section{Uji Heteroskedastisitas}

Untuk mengetahu apakah model regresi penelitian ini memenuhi asumsi heteroskedastisitas maka dilakukan uji Glejser, berikut adalah hasil Uji Glejse

\section{Tabel 4}

Uji Glejser

\begin{tabular}{|c|c|c|c|c|c|c|}
\hline \multicolumn{7}{|c|}{ Coefficients $^{\mathrm{a}}$} \\
\hline \multirow{2}{*}{\multicolumn{2}{|c|}{ Model }} & \multicolumn{2}{|c|}{ Unstandardized Coefficients } & \multirow{2}{*}{$\begin{array}{c}\begin{array}{c}\text { Standardized } \\
\text { Coefficients }\end{array} \\
\text { Beta } \\
\end{array}$} & \multirow[b]{2}{*}{$\mathrm{t}$} & \multirow[b]{2}{*}{ Sig. } \\
\hline & & $\mathrm{B}$ & Std. Error & & & \\
\hline \multirow[t]{4}{*}{1} & (Constant) & .049 & .055 & & .895 & .375 \\
\hline & Murabahah & .001 & .004 & .058 & .303 & .763 \\
\hline & Mudharabah & -.006 & .007 & -.176 & -.816 & .419 \\
\hline & B_Operasional & -.001 & .000 & -.257 & -1.405 & .167 \\
\hline
\end{tabular}


a. Dependent Variable: abres

Hasil uji glejser menunjukkan bahwa tidak ada satupun nilai koefisien regresi untuk seluruh variabel independen dalam penelitian ini yang berada di bawah nilai probability 0,05. Maka dapat disimpulkan tidak terjadinya heteroskedastisitas.

\section{Hasil Analisis Regresi Berganda}

\section{$Y=-38,555+2,797 X_{1}+0,796 X_{2}-0,064 X_{3}$}

Koefisien-koefisien pada persamaan regresi linier berganda di atas dapat di artikan sebagai berikut :

1. Nilai konstanta model persamaan regresi adalah sebesar -38,555. Artinya jika variabel pembiayaan murabahah, mudharabah dan biaya operasional bernilai nol, maka Return On Asset (ROA) adalah sebesar 38,555 satuan.

2. Nilai koefisien regresi pembiayaan murabahah $\left(\beta_{1}\right)$ adalah sebesar 2,797. Dengan demikian setiap peningkatan pembiayaan murabahah sebesar $1 \%$ maka Return On Asset (ROA) akan mengalami peningkatan sebesar 2,797. Dengan catatan vaiabel bebas dalam penelitian ini tidak mengalami perubahan (tetap). Hal ini menunjukkan bahwa terdapat hubungan yang positif antara pembiayaan murabahah dengan ROA. Kesimpulannya adalah apabila Bank memberikan pembiayaan murabahah maka akan meningkatkan ROA Bank itu sendiri.

3. Nilai koefisien regresi pembiayaan mudharabah $\left(\beta_{2}\right)$ adalah sebesar 0,796 . Dengan demikian setiap peningkatan pembiayaan mudharabah sebesar $1 \%$ maka Return On Asset( ROA) akan mengalami peningkatan sebesar 0,796 dengan catatan variabel bebas lain dalam penelitian ini tidak mengalami perubahan (tetap). Hal ini menunjukkan terdapat hubungan yang positif antara pembiayaan mudharabah dengan ROA. Kesimpulannya adalah apabila Bank memberikan pembiayaan mudharabah maka akan meningkatkan ROA Bank itu sendiri.

4. Nilai koefisien regresi biaya operasional $\left(\beta_{3}\right)$ adalah sebesar $-0,064$. Dengan demikian setiap peningkatan biaya operasional sebesar $1 \%$ maka Return On Asset(ROA) akan mengalami penurunan sebesar $-0,064$ dengan catatan variabel bebas lain dalam penelitian ini tidak mengalami perubahan (tetap). Hal ini menunjukkan bahwa terdapat hubungan yang negatif antara biaya operasional dengan ROA. Kesimpulannya adalah semakin tinggi biaya operasional yang dikeluarkan maka akan mengurangi tingkat ROA Bank itu sendiri.

\section{Uji Koefisien Determinasi}

\section{Tabel 5}

Uji Koefisien Determinasi

Model Summary ${ }^{\mathbf{b}}$

\begin{tabular}{|l|r|r|r|c|}
\hline Model & R & R Square & \multicolumn{1}{c|}{$\begin{array}{c}\text { Adjusted R } \\
\text { Square }\end{array}$} & $\begin{array}{c}\text { Std. Error of the } \\
\text { Estimate }\end{array}$ \\
\hline 1 & $.734^{\mathrm{a}}$ & .539 & .507 & .002685 \\
\hline
\end{tabular}

a. Predictors: (Constant), B_Operasional, Murabahah, Mudharabah

b. Dependent Variable: roa 
Berdasarkan tabel 5 di atas, diperoleh nilai $\mathrm{R}$ Square sebesar 0,539 atau $53,9 \%$ sehingga dapat disimpulkan bahwa persentase sumbangan pengaruh variabel independen (murabahah, mudharabah dan biaya operasional) terhadap variabel dependen (ROA) adalah sebesar $53,9 \%$ sedangkan sisanya $46,1 \%$ dipengaruhi oleh variabel lain yang tidak dimasukkan dalam penelitian ini.

\section{Uji Signifikan Simultan (F)}

\section{Tabel 6}

Uji Signifikan Simultan

\begin{tabular}{|ll|r|r|r|r|r|}
\hline \multicolumn{7}{|c|}{ ANOVA $^{\mathrm{a}}$} \\
\hline Model & & Sum of Squares & df & Mean Square & F & Sig. \\
\hline & Regression & 3.630 & 3 & 1.210 & 16.641 & $.000^{\mathrm{b}}$ \\
& Residual & 3.199 & 44 & .073 & & \\
& Total & 6.829 & 47 & & & \\
\hline
\end{tabular}

a. Dependent Variable: roa

b. Predictors: (Constant), B_Operasional, Murabahah, Mudharabah

Berdasarkan tabel 6 di atas dapat dan dapat diartikan bahwa pembiayaan diketahui bahwa nilai $\mathrm{F}_{\text {hitung }}$ 16,641> $>\mathrm{F}_{\text {tabel }}$ murabahah, mudharabah, dan biaya 2,84 dengan tingkat signifikansi 0,000 . operasional secara bersama-sama Nilai signifikansi tersebut lebih kecil berpengaruh signifikan terhadap return on daripada $\alpha$ 0,05. Sehingga dapat disimpulkan bahwa hipotesis 1 diterima asset.

\section{Uji Signifikan Parsial (t)}

Tabel 4.7

Uji Signifikan Parsial

\begin{tabular}{|c|c|c|c|c|c|c|}
\hline \multicolumn{7}{|c|}{ Coefficients $^{\mathrm{a}}$} \\
\hline \multirow{2}{*}{\multicolumn{2}{|c|}{ Model }} & \multicolumn{2}{|c|}{ Unstandardized Coefficients } & \multirow{2}{*}{$\begin{array}{c}\text { Standardized } \\
\text { Coefficients } \\
\text { Beta }\end{array}$} & \multirow[b]{2}{*}{$\mathrm{t}$} & \multirow[b]{2}{*}{ Sig. } \\
\hline & & $\mathrm{B}$ & Std. Error & & & \\
\hline \multirow[t]{4}{*}{1} & (Constant) & -38.555 & 8.460 & & -4.557 & .000 \\
\hline & Murabahah & 2.797 & .550 & .712 & 5.089 & .000 \\
\hline & Mudharabah & .796 & 1.083 & .117 & .735 & .466 \\
\hline & B_Operasional & -.064 & .060 & -.145 & -1.081 & .285 \\
\hline
\end{tabular}

a. Dependent Variable: roa

Hasil pengujian menunjukkan sebagai berikut:

1. Variabel Pembiayaan Murabahah $\left(\mathrm{X}_{1}\right)$ memiliki nilai $t_{\text {hitung } 5,089}>t_{\text {tabel }} 2,84$ dengan tingkat signifikansi sebesar 0,000 lebih kecil dari $\alpha 0,05$. Sehingga dapat disimpulkan Hipotesis 2 diterima dan dapat diartikan pembiayaan murabahah secara parsial berpengaruh terhadap return on asset.

2. Variabel Pembiayaan Mudharabah $\left(\mathrm{X}_{2}\right)$ memiliki nilai $t_{\text {hitung }} 0,735<$ $\mathrm{t}_{\text {tabel } 2,84}$ dengan tingkat signifikansi sebesar 0,466 lebih besar dari $\alpha 0,05$. 
Sehingga dapat disimpulkan Hipotesis 3 ditolak dan dapat diartikan pembiayaan mudharabah secara parsial tidak berpengaruh terhadap return on asset.

3. Variabel Biaya Operasional $\left(\mathrm{X}_{1}\right)$ memiliki nilai $t_{\text {hitung }}-1,081<\mathrm{t}_{\text {tabel }} 2,84$ dengan tingkat signifikansi sebesar 0,285 lebih besar dari $\alpha 0,05$. Sehingga dapat disimpulkan Hipotesis 4 ditolak dan dapat diartikan biaya operasional secara parsial tidak berpengaruh terhadap return on asset.

\section{KESIMPULAN}

1. Secara bersama-sama Pembiayaan Murabahah, Mudharabah, dan Biaya Operasional berpengaruh positif terhadap Return On Asset (ROA) pada Bank Umum Syariah dan Unit Usaha Syariah di Indonesia. Secara parsial pembiayaan murabahah berpengaruh positif dan signifikan terhadap terhadap Return On Asset (ROA) pada Bank Umum Syariah dan Unit Usaha Syariah di Indonesia.

2. Secara parsial pembiayaan mudharabah berpengaruh positif dan tidak signifikan terhadap terhadap Return On Asset (ROA) pada Bank Umum Syariah dan Unit Usaha Syariah di Indonesia.

3. Secara parsial biaya operasional berpengaruh negatif terhadap terhadap Return On Asset (ROA) pada Bank Umum Syariah dan Unit Usaha Syariah di Indonesia.

\section{DAFTAR PUSTAKA}

Agza, Yunita. 2016. "Analisis Pengaruh Pembiayaan Murabahah, Musyarakah, Dan Biaya Transaksi Terhadap Profitabilitas Bank Pembiayaan Rakyat Syariah Periode 2011-2016”. Skripsi Universitas Diponegoro Semarang
Antonio, M. S. (2001). Bank Syariah: Dari Teori ke Praktik. Jakarta: Gema Insani.

Hidayat, Anang. 2007. Strategi Six Sigma. Jakarta: PT Elex Media Komputindo.

Ghozali, Imam. 2013. Aplikasi Analisis Multivariate Dengan Program SPSS.Edisi ketujuh. Semarang: Badan Penerbit Universitas Diponegoro.

- 2011. Aplikasi Analisis Multivariate Dengan Program SPSS. Semarang: Badan Penerbit Universitas Diponegoro.

Kasmir. 2010. Analisis Laporan Keuangan. Jakarta: PT Raja Grafindo Persada.

Jusuf, Jopie. 2007. Analisis Kredit Untuk Account Officer: Cetakan ke 8. Jakarta: PT. Gramedia Pustaka Utama.

Fahmi, Irham. 2012. Analisis Laporan Keuangan. Cetakan Ke-2. Bandung: Alfabeta

Marliana Cut dan Fitri Meutia. 2016. Pengaruh Biaya Operasional, Dana Pihak Ketiga Dan Non Performing Finance Terhadap Pertumbuhan Laba Pada Perbankan Syariah Di Indonesia. Jurnal Ilmiah Mahasiswa Ekonomi Akuntansi (JIMEKA)

Muhammad. 2005. Manajemen Pembiayaan Bank Syariah. Yogyakarta: UPP AMP YKPN.

Nurhayati, Sri dan Wasilah. 2011. Akuntansi Syariah di Indonesia. Jakarta: Salemba Empat.

Malayu, S.P. Hasibuan, 2006, Dasardasar Perbankan, Jakarta: PT. Bumi Aksara

OJK. (2016a). Statistik Perbankan Syariah 2014-2016. Jakarta.

Ismail. 2015. Perbankan Syariah. Prenadamedia Group: Jakarta

OJK. (2016b). Laporan Triwulanan. Otoritas Jasa Keuangan Republik Indonesia. Jakarta.

OJK. (2016c). Metadata Statistik Perbankan Syariah. Departemen Perizinan dan Informasi Perbankan. 
Jakarta. Retrieved from www.ojk. go.id

UU No. 21 tahun 2008 tentang Perbankan Syariah

UU No.7 tahun 1992 tentang Perbankan

Sugiyono. 2012. Metode Penelitian Kuantitatif Kualitatif dan $R \& D$. Bandung: Alfabeta.

Wicaksana, Dwi Fany. 2011. Pengaruh Pembiayaan Mudharabah, Musyarakah dan Murabahah Terhadap Profitabilitas Bank Umum Syariah di Indonesia.Skripsi.Malang: Jurusan Akuntansi Fakultas Ekonomi Universitas Negeri Malang. 